\title{
CHEMICAL, PHYSICO-CHEMICAL AND SENSORY CHARACTERIZATION OF MIXED AÇAI (Euterpe oleracea) AND COCOA'S HONEY (Theobroma cacao) JELLIES ${ }^{1}$
}

\author{
BIANO ALVES DE MELO NETO ${ }^{2}$, ELCK ALMEIDA CARVALHO ${ }^{2}$, KAREN VALVERDE PONTES $^{3}$, \\ WALDEMAR DE SOUSA BARRETTO ${ }^{4}$, CÉLIO KERSUL DO SACRAMENTO
}

ABSTRACT - Four formulations of mixed açaí (Euterpe oleracea) (A) and cocoa's honey (Theobroma cacao $)(\mathrm{CH})$ jellies were prepared according to the following proportions: T1 $(40 \% \mathrm{~A}: 60 \% \mathrm{CH}), \mathrm{T} 2(50 \%$ A:50\% CH), T3 (60\% A: 40\% CH) and T4 (100\% A - control). All formulations were prepared using a rate $60: 40(\mathrm{w} / \mathrm{w})$ of sucrose and pulp, plus $0.5 \%$ pectin and the products reached to average of $65 \%$ soluble solids content. The jellies were analyzed by chemical and physicochemical (titratable acidity, $\mathrm{pH}$, soluble solid content, dry matter, total protein, lipids, vitamin $\mathrm{C}$ and calories) and sensory characteristics; also were evaluated levels of $\mathrm{P}, \mathrm{K}, \mathrm{Ca}, \mathrm{Mg}, \mathrm{Fe}, \mathrm{Zn}, \mathrm{Cu}$ and $\mathrm{Mn}$. It was used a hedonic scale of 7 points to evaluate the attributes: overall impression, spreadability, brightness, flavor, texture and color, and also was verified the purchase intention score. The titratable acidity and $\mathrm{pH}$ ranged from 0.46 to $0.64 \%$ and 3.35 to 3.64 , respectively, that are within the range found at most fruit jellies. The soluble solids content ranged between 65.2 and $65.5^{\circ}$ Brix. The sensory acceptance results showed that all treatments (T1, T2, T3 and T4) presented means of sensory attributes above 4, demonstrating good acceptance of the product, but the treatment $\mathrm{T} 1$ presented the higher scores for the evaluated attributes. Cocoa's honey added a positive influence on the attributes of color, texture and spreadability.

Index terms: sensory analysis, minerals, processing.

\section{CARACTERIZAÇÃO QUÍMICA, FÍSICO-QUIMICA E SENSORIAL DE GELEIAS MISTAS DE AÇAI (Euterpe oleracea) E MEL DE CACAU (Theobroma cacao)(Adequar o resumo de acordo com o abstract)}

RESUMO- Foram elaboradas quatro formulações de geleia com as seguintes proporções de açaí (Euterpe oleracea) (A) e mel de cacau (Theobroma cacao) (MC): T1 (60\% MC: 40\% A), T2 (50\% MC: 50\% A), T3 (40\% MC: $60 \%$ A) e T4 (100\% A - padrão). Todas as formulações apresentaram proporção final de polpa e açúcar de 60:40, com 0,5\% de pectina e teor médio de $65 \%$ de sólidos solúveis. As geleias foram analisadas quanto às características físico-químicas e sensoriais. Foram determinados a acidez titulável, $\mathrm{pH}$, sólidos solúveis, matéria seca, proteínas, lipídios, ácido ascórbico, valor calórico e os teores de $\mathrm{P}, \mathrm{K}$, $\mathrm{Ca}, \mathrm{Mg}, \mathrm{Fe}, \mathrm{Zn}, \mathrm{Cu}$ e $\mathrm{Mn}$. Foi usada uma escala hedônica de 7 pontos para avaliar os atributos: impressão global, espalhabilidade, brilho, sabor, textura e cor, e também a intenção de compra. A acidez titulável e o pH variaram entre 0,46 e $0,64 \%$ e 3,35 e 3,64, respectivamente, estando na faixa encontrada para a maioria das geleias de frutas enquanto o teor de sólidos solúveis variou entre 65,2 e $65,5^{\circ}$ Brix, enquadrando as geléias como do tipo extra. Os resultados da aceitação sensorial revelaram que todas as formulações das geleias (T1, T2, T3 e T4 - padrão) apresentaram nota média acima de 4, demonstrando boa aceitação do produto. $\mathrm{O}$ mel de cacau adicionado influenciou positivamente nos atributos cor, textura e espalhabilidade, mas o tratamento $\mathrm{T} 1$ apresentou as maiores notas para os atributos avaliados.

Termos para indexação: Análise sensorial, minerais, processamento.

\footnotetext{
1'(Trabalho 262-12). Recebido em: 29-10-2012. Aceito para publicação em: 17-06-2013.

${ }^{2}$ Eng $^{\circ}$ Alimentos, MSc., Núcleo de Tecnologia de Alimentos; Instituto Federal Baiano/Campus Uruçuca;, CEP 45.680-970, Uruçuca, BA; E-mails: biano.neto@gmail.com, elckcarvalho@gmail.com

${ }^{2}$ Eng $^{\mathrm{a}}$ Quimica, DSc. Professora Adjunta, Programa de Pós-Graduação em Engenharia Industrial (PEI), Universidade Federal da Bahia (UFBA), BA, Brasil. Rua Arisitides Novis n², Salvador-BA. E-mail: karenpontes@ufba.br

${ }^{4}$ Técnico Laboratório, Comissão Executiva do Plano da Lavoura Cacaueira (CEPLAC/CEPEC); BR-415, Rodovia Ilhéus/Itabuna, km 22, CEP 45.600-970, Ilhéus, BA. E-mail: waldemar@ceplac.gov.br.

${ }^{5}$ Eng $^{\mathrm{o}}$ Agrônomo, DSc., Universidade Estadual de Santa Cruz (UESC/DCAA); BR - 415, Rodovia Ilhéus/Itabuna, km 16, 45.662-900, E-mail:kersul@uesc.br
} 


\section{INTRODUCTION}

Cocoa and acai are fruit produced in the humid tropics and have considerable importance and use in the market. Their excellent nutritional value and high energetic value were conquered and consolidated nationally, with international expansion. The processed pulps of these fruits are commercialized in different forms, from "fresh", preferably frozen, until the development of energetic drinks, ice cream and popsicle, sweets, juices, nectars, jellies etc. The cocoa fruit is used primarily for making chocolate, but it also provides a clear liquid extracted from the cocoa mass which cover the seeds, known as "cocoa's honey".

In Brazil, jellies can be produced with a single fruit (simple jelly) or by mixing two or more fruits (mixed jelly). The preparation of these types of products means higher value and income for this agribusiness (DAMIANI et al., 2008, YUYAMA et al., 2008; ZOTARELLI et al., 2008; FERREIRA et al., 2011; LAGO-VANZELA et al., 2011; GUILHERME et al., 2012).

According to the Technical Standards Relating to Food and Beverage, in Resolution $\mathrm{n}^{\circ}$. 12, July 24, 1978 (BRASIL 1978) jelly fruit is the product obtained by cooking fruit, whole or in pieces, pulp or fruit juice, with sugar and water and concentrated to a gelatinous texture and can be subjected to addition of glucose or invert sugar. It cannot be artificially colored or flavored, being tolerated addition of pectin and acidulants, when necessary, to compensate any impairment of the natural content of the fruit acid and or pectin. The texture should be such that, when extracted from its container, is capable of maintaining the semi-solid state. A suitable combination of these components, both in quality and order placement during the processing, must be respected to ensure high quality of jelly (LAGO et al., 2006).

There are several ways to produce jellies, but generally the steps involved in processing are receiving the fruit, washing, pulping, addition of sucrose and pectin, concentration, filling, closing, cooling, labeling and storage. The final soluble solid content (expressed at ${ }^{\circ}$ Brix) may vary between 60 and 72 and the final $\mathrm{pH}$ between 2.8 and 3.3, however the commercial formulation is determined by consumer preference (DAMIANI et al., 2008; YUYAMA et al., 2008; ZOTARELLI et al., 2008).

The objective of this study was to determine the chemical and physico-chemical characteristics and evaluate the sensory acceptability of mixed açaí (Euterpe oleracea) and cocoa's honey (Theobroma cacao) jellies.

\section{MATERIAL AND METHODS}

This study was developed at the Núcleo de Tecnologia de Alimentos (NUTEC) of the Instituto Federal Baiano (IFBaiano), Campus Uruçuca, BA. All the fruits of açai and cocoa used in this study were obtained from plants grown in IFBaiano, Uruçuca municipality.

\section{Preparation of cocoa's honey and açai pulp and elaboration of jellies}

After harvesting, cocoa and acai fruit were transported to the Pilot Factory of IFBaiano, Campus Uruçuca, where they were selected to make the plot more uniform as the maturation stage and eliminate those fruit with mechanical injury or decay. Next, the fruits were washed and sanitized, for 15 minutes, in a solution of sodium hypochlorite $\left(50 \mathrm{mg} \mathrm{L}^{-1}\right)$ containing active chlorine. Cocoa's honey was extracted by pressing (Bonina, model ACLC-50, Brazil) and açai pulp by removing device in semiindustrial (Braesi, model DES-20, Brazil), after a previous cooking. Before the preparation of the jellies, was necessary to promote the dilution of açai using a rate 1:10 (w/w) of açai pulp and water. Jellies were obtained with different proportions of cocoa's honey $(\mathrm{CH})$ and açaí $(\mathrm{A})$ using a rate 60:40 (w/w) of pulp and sucrose, plus citrus pectin 105 (Doce Aroma, Brazil) at $0.5 \%(\mathrm{w} / \mathrm{w})$. Four treatments were studied: T1 (40\% A:60\% CH), T2 (50\% A:50\% CH), T3 (60\% A:40\% CH) and T4 (100\% A - control).

After mixing the pulp and $75 \%$ of sucrose was measured the soluble solids content and $\mathrm{pH}$, making the necessary adjustments (with addition of acid or base) to obtain a $\mathrm{pH}$ close to 3.0 which is ideal for making jelly (JACKIX, 1988).

The mixture was processed in an open pan with continuous mechanical movement (Incal Industrial Machinery, Brazil), for a period of 15 minutes. The addition of pectin is a critical step in the manufacturing process of jelly, therefore was added only at the end of the process so that it was not degraded by excessive cooking. The dissolution of the pectin was made by mixture of the pectin with the remaining $25 \%$ sucrose plus $150 \mathrm{~mL}$ of water at $60{ }^{\circ} \mathrm{C}$ under constant agitation.

When the jelly reached $63{ }^{\circ}$ Brix was added pectin diluted and mixed vigorously in order to incorporate it into the product completely. After reaching $65^{\circ}$ Brix, the jelly was bottled at temperatures around $94{ }^{\circ} \mathrm{C}$ in heat-resistant plastic bottles of $150 \mathrm{~g}$ capacity. Then, the containers were sealed, cooled and the products were identified with labels and kept under room temperature. 


\section{Chemical and Physico-chemical characterization}

The jellies were analyzed regarding titratable acidity (expressed as $\mathrm{g}$ of citric acid in $100 \mathrm{~g}^{-1}$ sample, direct titration of the material with $0.01 \mathrm{~N}$ $\mathrm{NaOH}, \mathrm{pH}$ in pHmeter Quimis, model Q400MT, Brazil, soluble solids content expressed as ${ }^{\circ}$ Brix in digital refractometer Tecnal, model R21300, Brazil, dry mater in oven with air circulation Tecnal, model TE-394/2, Brazil, total protein (\%), lipid content and ascorbic acid (expressed as mg of ascorbic acid in $100 \mathrm{~g}^{-1}$ sample) according to the methodologies established by Instituto Adolfo Lutz (IAL, 2008). The total caloric values of the jellies were calculated from the centesimal composition data, using the conversion of following factors: $9 \mathrm{kcal} \mathrm{g}^{-1}$ lipid, 4 kcal g${ }^{-1}$ protein, $4 \mathrm{kcal} \mathrm{g}^{-1}$ carbohydrate.

\section{Mineral profile}

The mineral profile of jellies was determined using atomic absorption spectrophotometry PerkinElmer, model 3030, USA, for $\mathrm{Ca}, \mathrm{Cu}, \mathrm{Mg}, \mathrm{Zn}$ and Mn, molecular absorption spectrophotometry Varian, series 6345, USA, for Fe and flame photometry Micronal, model B-262, Brazil for K .

\section{Sensory evaluation}

Samples containing approximately $5 \mathrm{~g}$ of jelly were served in $50 \mathrm{ml}$ plastic cups at room temperature. These were coded with three digit numbers and evaluated through an evaluation form, and the overall impression, spreadability, brightness, flavor, texture and color. Tasters were instructed to wash out the mouth with water filtered from sample to sample. The sensory acceptance test was conducted with 90 untrained tasters using a hedonic scale numerical of 7 points, with scores ranging from 1 (a) "dislike extremely" to seven (7) "like extremely." To be considered accepted, jellies should receive higher scores than the score (4) "indifferent" (ACOSTA et al., 2008).

\section{Statistical design}

For the chemical, physicochemical characterization and determination of the mineral profile of jellies, it was used a complately randomized design (CRD) with four (4) treatments and 4 (four) replicates. The results of sensory acceptability were evaluated by adopting the model of randomized block design (RBD), where treatments were four (4) formulations, blocks and repetitions were referring to the tasters. Comparisons between means were performed using analysis of variance (ANOVA) and Tukey test at $5 \%$ probability. Statistical analyzes were performed using the statistical program StatisticalAssistant, version 7.6 Beta.

\section{RESULTS AND DISCUSSION}

\section{Chemical and Physicochemical characterization}

The results of chemical and physicochemical characterization of mixed açai and cocoa's honey jellies are presented in Table 1 . The titratable acidity value of the treatmentsT1, T2 and T3 ranged from 0.46 to $0.64 \%$, being within the range of acidity recommended for most fruit jellies (YUYAMA et al., 2008; FOPPA et al., 2009; LAGO-VANZELA et al., 2011). The titratable acidity of the control treatment (T4) with $100 \%$ of açai pulp was $0.20 \%$. Thus, it was observed that the variation of the titratable acidity in the other treatments is directly associated with the gradual increase of concentration of cocoa's honey. Regarding to $\mathrm{pH}$, it was found that the same has been reduced due to the higher proportion of cocoa's honey used in the formulation. Similar result was found by Ferreira et al. (2011) with mixed watermelon and tamarind jelly, where the addition of tamarind promoted an increase in acidity of jelly. The soluble solids content of the treatments ranged between $65.2^{\circ} \mathrm{Brix}$ (T3) and $65.5^{\circ} \mathrm{Brix}$ (T1). Similar values were found by Viana et al. (2012) in papaya and araza boi jelly (63.9 to $\left.65.4{ }^{\circ} \mathrm{Brix}\right)$ and by Damiani et al. (2012) in mixed araça and marolo jam $\left(68,40\right.$ to $72,18^{\circ}$ Brix. These results also corroborate those reported by Damiani et al. (2008) who obtained the fruit jellies with total soluble solids content in the range of $65^{\circ}$ Brix.

However, these values are lower than those obtained by Lago-Vanzela et al. (2011) for mangoes jellies ( $69^{\circ}$ Brix) and by Singh et al. (2009) for mixed pineapple and papaya jelly $\left(70.5^{\circ}\right.$ Brix $)$ and papaya with orange $\left(72.5^{\circ}\right.$ Brix). Mota (2006), in a study of jellies formulated with different varieties of blackberry, found lower levels of soluble solids content (47-58 ${ }^{\circ}$ Brix) than in the present study. According to Jackix (1988) the soluble solids ideal for jellies are $67.5^{\circ} \mathrm{Brix}$, and to lower values (64 ${ }^{\circ}$ Brix $)$, the gel becomes weaker and above $\left(71^{\circ}\right.$ Brix $)$ can occur crystallization of the jelly.

The dry matter content of the four treatments ranged from $60.24 \%$ (T3) to $62.44 \%$ (T1), which means that moisture ranged from $35.56 \%$ (T1) to $39.76 \%$ (T3), similar to levels found in the Lago et al. (2006) and Lago-Vanzela et al. (2011) study in jelly of jambolan (29.6\%) and otaheite apple (29.5\%). respectively. Mota (2006) found higher moisture contents ( 42.84 to $46.44 \%$ ) in jellies made 
from different varieties of blackberry. According to Viana et al. (2012), the moisture content in jellies is directly related to the conservation of the product during storage.

The total protein content of the treatments $\mathrm{T} 1$, $\mathrm{T} 2$ and $\mathrm{T} 3$ was $0.44 \%, 047 \%$ and $0.51 \%$, respectively. The control treatment (T4), prepared only with açai pulp was $0.54 \%$. Cocoa's honey and the açai pulp present low protein concentration. Smaller amounts of proteins also were found by Granada et al. (2005), studying pineapple jelly $(0.21 \%, 0.22 \%, 0.26 \%$ and $0.28 \%$ ), and by Foppa et al. (2009) at Housui and D'agua pear jelly (0.17\%). Lago-Vanzela et al. (2011) found higher levels in pulp and peel "cajá manga" jelly $(1.47 \%)$.

The lipid content in the control treatment $(5.51 \%)$ is considered high when compared with other jellies (YUYUMA et al., 2008; LAGO-VANZELA et al., 2011). This fact probably is associated with the higher concentration of lipids present in the fruit of açai and its pulp. Compared to the lipid content of others treatments (T1, T2 and T3), 3.50\%, 3.66\% and $3.95 \%$, respectively can be deduced that the addition of cocoa's honey decrease the concentration of this nutrient. Yuyama et al (2008) studying cubiu jellies with xylitol and with sucrose found lipid content of $0.34 \%$ and $0.38 \%$, respectively.

There is little information in the literature on the content of ascorbic acid in jellies. In the control treatment, the ascorbic acid content was $28.96 \mathrm{mg}$ $100 \mathrm{~g}^{-1}$. In comparison to the other treatments (T1, T2 and T3), $13.08 \%, 10.87 \%$ and $10.36 \%$, respectively, it was found that the addition of cocoa honey also influenced the decrease in concentration of that nutrient. The amount of calories of the treatments $\mathrm{T} 1, \mathrm{~T} 2$ and $\mathrm{T} 3$ ranged from $303.09 \mathrm{kcal} 100 \mathrm{~g}^{-1}$ to

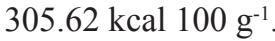

The results of the mineral profile of mixed açai and cocoa honey jellies are presented in Table 2. No difference was observed between the formulations with respect to $\mathrm{P}$ element. With respect to the element $\mathrm{K}$, there was no difference between the formulations T1, T2 and T3. However, there was difference between the three formulations and the standard T4. The Fe content of the treatments T3 and T4 did not differ each other, however, there was difference between the other treatments $\mathrm{T} 1$ and T2. Also, was observed a difference between the formulations for $\mathrm{Ca}$ and $\mathrm{Mn}$. Among the fractions of minerals present in the mixed açai and honey cacao jellies presented in the Table 2, the Fe element, due its importance, deserves mention, because it showed

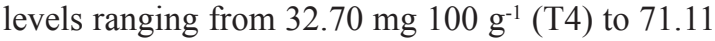
$\mathrm{mg} 100 \mathrm{~g}^{-1}$ (T1) equivalent, on average, four times higher the recommended daily dietary intended for an adult, considering a $100 \mathrm{~g}$ portion of the product. The mineral element, phosphorus, showed levels within the recommended daily value and Mn exceeded by ten times the daily value, considering the portion of $100 \mathrm{~g}$ of the product, since the fractions of $\mathrm{K}, \mathrm{Ca}$, $\mathrm{Mg}, \mathrm{Zn}$ and $\mathrm{Cu}$ showed up at low of the daily values.

\section{Sensory acceptance}

The results of the sensory acceptance of mixed açai and cocoa's honey jellies are presented in Table 3. It was observed that none of the treatments presented score below 4, that correspond to the rejection zone (CAMARGO et al., 2007), according to hedonic scale of 7 points used. So it can be inferred that the products presented acceptable sensory characteristics for marketing. However, there was statistically significant differences $(p<0.05)$ between the treatments except flavor and texture attributes.

There were variations in the preference of the jelly with regard to these attributes, since the treatment $\mathrm{T} 1$, with more cocoa's honey, presented a better acceptance, with scores between 5.0 and 6.0, corresponding to the hedonic terms "like moderately and like much", respectively. Zotarelli et al. (2008) observed that in mixed guava and passion fruit jelly, the higher concentrations of guava benefited the acceptance of the product by the judges. Ferreira et al. (2011) also found that the addition of watermelon improved acceptance of tamarind jelly.

Regarding the flavor attribute, when compared with the control treatment (T4), it was found that the addition of honey cocoa did not affect sensory acceptance of jellies (T1, T2 and T3), which maintained the characteristic flavor of acai.

Damiani et al. (2008) explained that the texture of the jelly is the result of two factors of the structure: gelling, linked to the concentration of pectin, and stiffness, related to the concentration of sugar and acid. The cocoa's honey is a product known for its acidity and high levels of sugar and pectin and its addition contributed to the improve flavor and especially texture of jelly. However, there was no significant influence over these two attributes.

There was no significant difference ( $\mathrm{p} \leq$ 0.05 ) between the treatments $\mathrm{T} 1$ and $\mathrm{T} 2, \mathrm{~T} 4$ and $\mathrm{T} 3$, with reference to the attribute spreadability. The spreadability is directly related to the uniformity and rigidity of the gel formed and the resulting gel structure which is connected to the concentration of pectin, sugar and acid. Thus, the amount of pectin added, as well as the intrinsic characteristics of cocoa's honey influenced positively this attribute. 
TABLE 1 - Means of chemical and physicochemical characteristics of the mixed açaí (Euterpe oleracea) (A) and cocoa's honey (Theobroma cacao) $(\mathrm{CH})$ jellies.

\begin{tabular}{lcccccc}
\hline \multirow{2}{*}{ Parameters evaluated } & \multicolumn{7}{c}{ Treatments } \\
\cline { 2 - 7 } & $\mathrm{T} 1$ & $\mathrm{~T} 2$ & $\mathrm{~T} 3$ & $\mathrm{~T} 4$ & LSD $^{*}$ & F Sample \\
\hline Acidity (\%) & $0.45 \mathrm{c}$ & $0.55 \mathrm{~b}$ & $0.63 \mathrm{a}$ & $0.08 \mathrm{~d}$ & 0.06 & $284.77^{* *}$ \\
$\mathrm{pH}$ & $3.62 \mathrm{~b}$ & $3.61 \mathrm{~b}$ & $3.58 \mathrm{~b}$ & $4.34 \mathrm{a}$ & 0.20 & $68.33^{* *}$ \\
Soluble Solids ( ${ }^{\circ}$ Brix) & $65.50 \mathrm{a}$ & $65.30 \mathrm{a}$ & $65.20 \mathrm{a}$ & $64.90 \mathrm{a}$ & 1.57 & $0.30^{\mathrm{ns}}$ \\
Dry Matter (\%) & $66.43 \mathrm{a}$ & $60.63 \mathrm{bc}$ & $58.64 \mathrm{c}$ & $62.08 \mathrm{~b}$ & 3.19 & $21.84^{* *}$ \\
Protein (\%) & $0.43 \mathrm{~b}$ & $0.46 \mathrm{ab}$ & $0.52 \mathrm{a}$ & $0.54 \mathrm{a}$ & 0.06 & $7.68^{* *}$ \\
Lipids (\%) & $3.50 \mathrm{a}$ & $3.66 \mathrm{a}$ & $3.95 \mathrm{a}$ & $5.51 \mathrm{a}$ & 0.65 & $0.92^{\mathrm{ns}}$ \\
Acid ascorbic (mg 100g $\left.{ }^{-1}\right)$ & $13.08 \mathrm{~b}$ & $10.87 \mathrm{~b}$ & $10.36 \mathrm{~b}$ & $59.96 \mathrm{a}$ & 14.84 & $54.11^{* *}$ \\
Energy Value (Kcal) & $305.08 \mathrm{a}$ & $287.70 \mathrm{a}$ & $304.61 \mathrm{a}$ & $303.08 \mathrm{a}$ & 74.42 & $0.25^{\mathrm{ns}}$ \\
\hline
\end{tabular}

T1 (40\%A:60\%CH), T2 (50\%A:50\%CH), T3 (60\%A:40\%CH), T4 (100\%A-control).

Means with the same letters in the same line indicate no significant difference between samples by Tukey test $(\mathrm{p} \leq 0.05)$.

*LSD (least significative difference)

TABLE 2 - Levels of mineral formulations of mixed açaí (Euterpe oleracea) and cocoa's honey (Theobroma cacao) jelly with different concentrations.

\begin{tabular}{ccccccc}
\hline \multirow{2}{*}{ Parameters evaluated } & \multicolumn{7}{c}{ Treatments } \\
\cline { 2 - 7 } & $\mathrm{T} 1$ & $\mathrm{~T} 2$ & $\mathrm{~T} 3$ & $\mathrm{~T} 4$ & LSD* & F Sample \\
\hline $\mathrm{P}$ & $1.54 \mathrm{a}$ & $1.51 \mathrm{a}$ & $1.52 \mathrm{a}$ & $1.53 \mathrm{a}$ & 0.07 & $0.46^{\text {ns }}$ \\
$\mathrm{K}$ & $2.15 \mathrm{a}$ & $1.95 \mathrm{a}$ & $2.3 \mathrm{a}$ & $1.55 \mathrm{~b}$ & 0.39 & $14.08^{* *}$ \\
$\mathrm{Ca}$ & $0.42 \mathrm{bc}$ & $0.62 \mathrm{~b}$ & $0.85 \mathrm{a}$ & $0.38 \mathrm{c}$ & 0.21 & $20.98^{* *}$ \\
$\mathrm{Mg}$ & $0.22 \mathrm{a}$ & $0.22 \mathrm{a}$ & $0.26 \mathrm{a}$ & $0.12 \mathrm{~b}$ & 0.07 & $13.79^{* *}$ \\
$\mathrm{Fe}$ & $71.11 \mathrm{a}$ & $45.99 \mathrm{~b}$ & $30.39 \mathrm{c}$ & $32.70 \mathrm{c}$ & 10.08 & $70.42^{* *}$ \\
$\mathrm{Zn}$ & $2.25 \mathrm{~b}$ & $4.52 \mathrm{a}$ & $5.14 \mathrm{a}$ & $5.57 \mathrm{a}$ & 1.35 & $24.36^{* *}$ \\
$\mathrm{Cu}$ & $12.42 \mathrm{~b}$ & $12.49 \mathrm{~b}$ & $17.62 \mathrm{a}$ & $12.64 \mathrm{~b}$ & 3.34 & $11.93^{* *}$ \\
$\mathrm{Mn}$ & $10.58 \mathrm{~b}$ & $17.10 \mathrm{ab}$ & $20.56 \mathrm{a}$ & $14.76 \mathrm{ab}$ & 6.68 & $8.05^{* *}$ \\
\hline
\end{tabular}

P. K. Ca e Mg (g $\left.100 \mathrm{~g}^{-1}\right) /$ Fe. Zn. Cu e $\mathrm{Mg}\left(\mathrm{mg} 100 \mathrm{~g}^{-1}\right)$

T1 (40\%A:60\% CH). T2 (50\%A:50\%CH). T3 (60\%A:40\%CH). T4 (100\%A-control).

Means with the same letters in the same line indicate no significant difference between samples by Tukey test $(\mathrm{p} \leq 0.05)$.

*LSD (least significative difference) 
TABLE 3 - Means of the scores assigned by the tasters for sensory attributes of the mixed açai and cocoa's honey jellies.

\begin{tabular}{ccccccc}
\hline Treatments & $\begin{array}{c}\text { Overall } \\
\text { impression }\end{array}$ & Color & Texture & Flavor & Brightness & Spreadability \\
\hline T1 & $5.45 \mathrm{a}$ & $5.71 \mathrm{a}$ & $5.55 \mathrm{a}$ & $5.31 \mathrm{a}$ & $5.51 \mathrm{a}$ & $5.24 \mathrm{a}$ \\
T2 & $4.88 \mathrm{a}$ & $5.35 \mathrm{a}$ & $4.79 \mathrm{a}$ & $5.10 \mathrm{a}$ & $5.12 \mathrm{a}$ & $4.20 \mathrm{bc}$ \\
T3 & $4.12 \mathrm{~b}$ & $5.73 \mathrm{a}$ & $4.69 \mathrm{a}$ & $4.65 \mathrm{a}$ & $4.65 \mathrm{~b}$ & $4.00 \mathrm{c}$ \\
T4 & $4.77 \mathrm{ab}$ & $4.41 \mathrm{~b}$ & $5.18 \mathrm{a}$ & $4.86 \mathrm{a}$ & $4.92 \mathrm{ab}$ & $4.37 \mathrm{abc}$ \\
LSD** & 0.7451 & 0.7398 & 0.8155 & 0.8011 & 0.7922 & 0.9181 \\
F Sample & 6.41 & 8.28 & 28.89 & 10.13 & 2.85 & 5.21 \\
\hline
\end{tabular}

T1 (40\%A:60\%CH). T2 (50\%A:50\%CH). T3 (60\%A:40\%CH). T4 (100\%A-control).

Means with the same letters in the same colune indicate no significant difference between samples by Tukey test $(\mathrm{p} \leq 0.05)$.

**LSD (least significative difference).

\section{CONCLUSIONS}

The treatments showed significant differences with respect to mineral contents, except for $\mathrm{P}$ and.

Every formulations of mixed jellies presented good sensory acceptance but the treatment T1 (40\% açai: $60 \%$ cocoa's honey) presented the higher scores for the evaluated attributes.

\section{ACKNOWLEDGMENTS}

The authors are grateful to the Fundação de Apoio à Pesquisa do Estado da Bahia (FAPESB) and IFBaiano for financially supporting this project.

\section{REFERENCES}

Acosta, O.; VIQUEZ, F.; CUBERO, E. Optimization of low calorie mixed fruit jelly by response surface methodology. Food Quality and Preference, Barking, v.19 n.1 p.79-85, 2008.

BRASIL. Leis, Decretos, etc. Decreto n. 12.486, de 20 de outubro de 1978. Normas Técnicas Especiais Relativas a Alimentos e Bebidas. Diário Oficial do Estado de São Paulo, São Paulo, SP, 21 out. 1978. p. 3-25.

CAMARGO, G. A.; HAJ-ISA, N.; QUEIROZ, M. R. Avaliação da qualidade de tomate seco em conserva. Revista Brasileira de Engenharia Agrícola e Ambiental, Campina Grande, v.11 n.5, p.521-526, 2007.
DAMIANI, C.; ASQUIERI, E.R.; LAGE, M.E.;OLIVEIRA, R.A.; SILVA, F.A.; PEREIRA, D.E.P.; VILAS BOAS, V.B. Study of the shelf-life of a mixed araça (Psidium guineensis Sw.) and marolo (Annona crassiflora Mart.) Jam. Ciência e Tecnologia de Alimentos, Campinas, v.32, n.2, 2012.

DAMIANI, C.; VILAS BOAS, E. V. B.; SOARES JÜNIOR, M. S.; CALIARI, M.; PAULA, M. L.; PEREIRA, D. E. P.; SILVA, A. G. M. Análise física, sensorial e microbiológica de geleias de manga formuladas com diferentes níveis de cascas em substituição à polpa. Ciência Rural, Santa Maria, v.38, n.5, p.1.418-1.423, 2008.

FERREIRA, R.M.A.; AROUCHA, E.M.M.; GÓIS, V.A.; SILVA, D.K.; SOUSA, C.M.G. Qualidade sensorial de geléia mista de melancia e tamarindo. Revista Caatinga, Mossoró, v.24, n.2, p.202-206, 2011.

FOPPA, T.; TSUZUKI, M. M.; SANTOS, C. E. S. Caracterização físico-química da geleia de pera elaborada através de duas cultivares diferentes: Perad'água e Housui. Revista Brasileira de Produtos Agroindustriais, Campina Grande, v.11, n.1, p.2125, 2009.

GRANADA，G. G.; ZAMBIAZI，R. C.; MENDONÇA, C. R. B.; SILVA, E. Caracterização física, química, microbiológica e sensorial de geleias light de abacaxi. Ciência e Tecnologia de Alimentos, Campinas, v.225, n.4, p.629-635, 2005. 
GUILHERME, P.R.; PESSATTTO, C.C.; ZAICA, W.K.; QUAST, C.; QUAST, L.B.; CORMENESE, R.S.S.; RAUPP, D.S. Desenvolvimento de geleia de tamarillo contendo polpa integral. Brazilian Journal of Food Technology, Campinas, v.15, n.2, p.141-149, 2012.

IAL - Instituto Adolfo Lutz. Métodos físicoquímicos para análise de alimentos. São Paulo, 2008. 1020 p.

JACKIX, M. H. Doces, geleias e frutas em calda: teórico e prático. São Paulo: Unicamp, 1988. 178 p.

LAGO, E. S.; GOMES, E.; SILVA, R. Produção de geleia de jambolão (Syzygium cumini Lamarck): processamento, parâmetros físico-químicos e avaliação sensorial. Ciência e Tecnologia de Alimentos, Campinas, v.26, n.4, p.847-852, 2006.

LAGO-VANZELA, E. S.; RAMIN, P.; GUEZUMSZA, M. A.; SAMTPS, G. V.; GOMES, E.; SILVA, R. Chemical and sensory characteristics of pulp and peel cajá-manga (Spondias cytherea Sonn.) jelly. Ciência e Tecnologia de Alimentos, Campinas, v.31, n.2, p.398-405, 2011.
MOTA, R. V. Caracterização física e química de geleia de amora-preta. Ciência e Tecnologia de Alimentos, Campinas, v.26, n.3, p.539-543, 2006.

SINGH, S.; JAIN, S.; SINGH, S. P.; SINGH, D. Quality changes in fruit jellies from combinations of different fruit pulps. Journal of Food Processing and Preservation, Westport, v.33, p.41-47, 2009.

VIANA, E.S.; REIS, R.C.; SACRAMENTO, C. K. . Caracterização físico-química e sensorial de geleia de mamão com araçá-boi. Revista Brasileira de Fruticultura, Jaboticabal, v. 34, n.4 , p. 1154-1164, 2012.

YUYAMA, L. K. O.; PANTOJA, L.; MAEDA, R.N.; AGUIAR, J.P.L.; SILVA, J.P.L.A. Desenvolvimento e aceitabilidade de geleia dietética de cubiu (Solanum sessiliflorum Dunal). Ciência e Tecnologia de Alimentos, Campinas, v. 28, n.4, p.929-934, 2008.

ZOTARELLI, M. F.; ZANATTA E. Avaliação de geleias mistas de goiaba e maracujá. Revista Ceres, Viçosa, MG, v.55, n.6, p.562-567, 2008. 